\title{
PENGARUH STRATEGI PEMBELAJARAN DAN GAYA BELAJAR TERHADAP HASIL BELAJAR IPS GEOGRAFI
}

\author{
Nurdin Saragih ${ }^{1}$ dan Harun Sitompul ${ }^{2}$ \\ SMP Negeri 1 Pangururan Kabupaten Samosir' ${ }^{1}$ dan Universitas Negeri Medan ${ }^{2}$ \\ nurdinsaragih@yahoo.com ${ }^{l}$ dan prof_runsit@yahoo.co.id ${ }^{2}$
}

\begin{abstract}
Abstrak: Tujuan penelitian ini adalah untuk mengetahui: (1) hasil belajar IPS Geografi siswa yang diajar dengan Strategi pembelajaran berbasis Genius Learning lebih tinggi daripada dengan strategi pembelajaran Ekspositori, (2) hasil belajar IPS Geografi siswa yang memiliki gaya belajar konvergen,lebih tinggi daripada yang memiliki gaya belajar divergen (3) interaksi antara strategi pembelajaran dengan gaya belajar dalam mempengaruhi hasil belajar IPS Geografi siswa. Metode penelitian menggunakan quasi eksperimen dengan desain penelitian factorial $2 \times 2$. Teknik analisis data menggunakan ANAVA dua jalur pada taraf signifikan $\alpha=0,05$. Hasil penelitian menunjukkan bahwa: (1) hasil belajar IPS Geografi siswa yang diajar dengan strategi pembelajaran berbasis Genius Learning lebih tinggi dibandingkan strategi pembelajaran ekspositori; (2) hasil belajar IPS Geografi siswa yang memiliki gaya belajar divergen lebih tinggi dibandingkan gaya belajar konvergen; dan (3) terdapat interaksi antara strategi pembelajaran berbasis Genius Learning dan gaya belajar dalam mempengaruhi hasil belajar IPS Geografi. Interaksi hanya terlihat untuk gaya belajar konvergen dan Divergen. Siswa dengan gaya belajar Konvergen memperoleh hasil belajar yang lebih tinggi jika diajar dengan strategi pembelajaran berbasis Genius Learning.
\end{abstract}

Kata Kunci: strategi pembelajaran, gaya belajar, hasil belajar IPS geografi

Abstract: The aim of this study was to determine: (1) the results of social studies Geography students who are taught by learning strategy based Genius Learning is higher than with learning strategies Expository, (2) the results of social studies Geography students who have learning styles converge, higher than which has a divergent learning style (3) the interaction between learning strategy and learning styles in influencing student learning outcomes IPS Geography. The research method using a quasi-experimental design with $2 \times 2$ factorial study data were analyzed using ANOVA two lines at significant level $\alpha=0.05$. The results showed that: (1) the results of social studies Geography students who are taught by Genius based learning strategies Learning higher than expository teaching strategy; (2) the results of social studies Geography students who have a learning style diverges higher than converging learning styles; and (3) there is interaction between learning strategy based Genius Learning and learning styles in affecting social studies Geography. Interaction only visible for converging and diverging learning styles. Students with learning styles acquire Convergent learning outcomes are higher when taught by Genius based learning strategies Learning.

Keywords: learning strategies, learning styles, learning outcomes IPS geography

\section{PENDAHULUAN}

Pembelajaran dengan cara membahas buku pegangan, memberi contoh soal adalah metode yang lazim digunakan guru saat ini yang dikenal dengan strategi ekspositori. Kegiatan utama yang dilakukan dalam strategi ini adalah mendengar dan mencatat apa yang disampaikan guru. Ciri-ciri pembelajaran ini adalah pembelajaran secara klasikal, para siswa tidak mengetahui apa tujuan mereka belajar pada hari itu, guru biasanya mengajar dengan berpedoman pada buku teks atau LKS, dengan mengutamakan metode ceramah dan kadangkadang tanya jawab.

Di SMP Negeri 1 Pangururan Kabupaten Samosir saat ini, kondisi pembelajaran IPS masih belum mengalami perubahan yang mengarah pada pembelajaran yang dapat membuat siswa bertambah pengetahuan. Kenyataan menunjukkan bahwa nilai siswa yang masih rendah dan apa yang digariskan dalam Tujuan Pembelajaran masih kurang maksimal. Masalah di atas menunjukkan bahwa perolehan hasil belajar IPS Geografi 
masih cenderung kurang memuaskan. Hal tersebut, diperkirakan karena kurangnya pemahaman siswa terhadap konsep pembelajaran IPS Geografi. Mereka menganggap pelajaran IPS Geografi sulit dipahami.

Menyikapi masalah di atas, perlu adanya upaya yang dilakukan oleh guru untuk menggunakan strategi mengajar yang membuat suasana belajar menjadi lebih menyenangkan sehingga mampu memotivasi siswa untuk belajar. Suparno seperti dikutip Atmadi dan Setyaningsih (2000:186) mengatakan bahwa:"Guru dalam proses belajar mengajar, harus lebih memperhatikan apa yang disukai siswa, apa yang tidak disukai siswa, yang membantu siswa belajar dan yang menghambat siswa belajar". Selain itu, strategi yang digunakan juga harus memaksimalkan potensi siswa dengan memperhatikan keunikan setiap siswa baik gaya belajarnya, kecerdasan dominannya, dan memperhitungkan faktorfaktor lain yang mampu menunjang proses belajar mengajar di kelas.

Wasliman seperti yang dikutip Fajar (2004) menyatakan bahwa, potensi setiap peserta didik sebenarnya berbeda. Untuk itu, perlu dikembangkan model-model pembelajaran yang mengakomodasikan perbedaan potensi dan sekaligus memberikan seluas-luasnya untuk secara aktif menumbuhkan kreatifitas peserta didik, agar kecerdasannya berkembang secara optimal dan proporsional.

Selain faktor-faktor dari guru, faktor yang berasal dari dalam diri siswa juga berpengaruh dalam proses pembelajaran. Faktor yang mempengaruhi hasil belajar yang berasal dari siswa sendiri salah satunya adalah karakteristik siswa itu sendiri. Uno (2006:143) menjelaskan bahwa karakteristik siswa merupakan salah satu hal yang perlu diidentifikasi oleh guru untuk digunakan sebagai petunjuk dalam mengembangkan program pembelajaran. Karakteristik yang diidentifikasi tersebut dapat berupa bakat, motivasi, gaya belajar, kemampuan berfikir, minat sikap, kemampuan awal, kecerdasan dan sebagainya.

Dunn dan Dunn seperti dikutip Prashnig (2007:31) mengungkapkan bahwa gaya belajar adalah cara manusia mulai berkonsentrasi, menyerap, memproses, dan menampung informasi yang baru dan sulit. Hasil belajar optimal akan diperoleh apabila beragam perbedaan seperti kebiasaan, minat, dan gaya belajar pada peserta didik diakomodasi oleh guru melalui pilihan metode mengajar dan materi ajar yang sesuai dengan gaya belajar peserta didik. Pembelajaran bidang studi apapun, bisa ditingkatkan kualitasnya, apabila guru memahami karakteristik peserta didik dengan baik termasuk gaya belajar mereka. Kemudian, informasi tentang peserta didik tersebut menjadi bahan pertimbangan bagi guru dalam memilih metode, teknik mengajar, dan materi ajar yang sesuai dengan keberagaman gaya belajar peserta didik.

Gagne mendefinisikan belajar adalah sebagai hasil dari interaksi antara individu dengan lingkungannya (Gagne \& Driscoll, 1989:21). Gagne seperti yang dikutip Bigge (1982:141) mendefinisikan belajar sebagai perubahan dalam prilaku dan keterampilan manusia yang dapat dipakai, dan bukan dianggap berasal dari proses pertumbuhan. Gagne memandang belajar sebagai proses perubahan prilaku akibat pengalaman yang dialaminya.

Chaplin seperti yang dikutip Syah (2008:65) memberikan batasan definisi belajar yang menyinggung teori belajar Gagne dan Skinner. Chaplin membatasi belajar dengan dua rumusan yaitu : (1) perolehan perubahan tingkah laku yang relatif menetap sebagai akibat latihan dan pengalaman, (2) proses memperoleh respon-respon sebagai akibat adanya latihan khusus.

Reber seperti yang dikutip Syah (2008:66) membatasi belajar dengan dua definisi. Pertama, belajar adalah proses memperoleh pengetahuan. Istilah ini lebih sering dipakai dalam pembahasan psikologi kognitif. Kedua, belajar adalah suatu perubahan kemampuan bereaksi yang relatif langgeng sebagai hasil latihan yang diperkuat. Dalam definisi ini terkandung empat istilah yang penting dalam memahami makna belajar yaitu : (1) relatively permanent (yang secara umum menetap), (2) response potentiality (kemampuan bereaksi), (3) reinforced (yang diperkuat), dan (4) practice (latihan).

Biggs seperti yang dikutip Syah (2008:67) mendefinisikan belajar dalam tiga rumusan, yaitu : rumusan kuantitatif, rumusan institusional dan kualitatif. Secara kuantitatif belajar adalah kegiatan pengembangan kemampuan kognitif dengan fakta sebanyakbanyaknya. Dalam hal ini, belajar dipandang dari sudut seberapa banyak materi yang 
dikuasai siswa. Secara intitusional belajar dipandang sebagai proses validasi terhadap penguasaan siswa atas materi-materi yang telah dipelajari. Ukurannya adalah semakin baik mutu mengajar guru maka semakin baik pula mutu hasil belajar siswa. Sedangkan secara kualitatif belajar adalah proses memperoleh arti dan pemahaman serta cara menafsirkan dunia di sekeliling siswa. Belajar di sini difokuskan pada tercapainya daya fikir dan tindakan yang berkualitas untuk memecahkan masalah yang dihadapi siswa.

Gagne (Gagne \& Driscoll, 1989:44) membagi hasil belajar dalam lima tipe yaitu, (1) informasi verbal, pengetahuan verbal ini disimpan sebagai jaringan proposisi-proposisi di mana informasi verbal dapat diperoleh dari kegiatan pembelajaran di sekolah, buku, radio, $\mathrm{TV}$, percakapan orang lain dan lain-lain, (2) keterampilan intelektual, memungkinkan seseorang berinteraksi dengan lingkungannya melalui penggunaan simbol atau gagasan, (3) strategi kognitif, merupakan proses kontrol, yaitu proses internal yang digunakan siswa untuk memilih atau mengubah cara-cara memberikan perhatian, belajar, mengingat dan berfikir. (4) sikap merupakan pembawaan yang dapat dipelajari, dan dapat mempengaruhi prilaku seseorang terhadap lingkungannya dan (5) keterampilan motorik yaitu keterampilan yang tidak hanya mencakup kegiatan fisik, melainkan juga kegiatan-kegiatan motorik yang digabung dengan keterampilan intelektual.

Reigeluth (1983) mendefinisikan hasil belajar sebagai berbagai akibat yang dapat dipakai untuk mengukur kegunaan berbagai macam metode pembelajaran dalam berbagai kondisi. Menurutnya, hasil pembelajaran harus memiliki efektifitas, efesiensi dan daya tarik. Efektifitas diukur dari tingkat pencapaian hasil belajar yang diperoleh oleh peserta didik, baik secara kualitas maupun kuantitas. Secara kualitas hasil belajar menunjukkan kebermaknaan isi bahan yang dipelajari dalam kehidupan sehari-hari, sedangkan kuantitas menunjukkan jumlah variasi hasil belajar yang dapat dicapai oleh peserta didik. Efesiensi diukur berdasarkan waktu yang dibutuhkan peserta didik untuk belajar, dalam arti semakin sedikit waktu yang dibutuhkan peserta didik untuk memahami isi materi pelajaran, maka semakin efisien hasil belajar yang diperoleh. Sedangkan daya tarik diukur dari ada tidaknya kecenderungan peserta didik termotivasi untuk belajar lebih lanjut dalam arti mengembangkan wawasan berdasarkan hasil belajar yang telah diperoleh.

Bloom seperti yang dikutip Anderson, dkk (2001) mengklasifikasikan hasil belajar dalam tiga ranah yaitu ranah kognitif, afektif dan psikomotorik. Ranah kognitif terbagi dalam 6 tingkatan yaitu ingatan, pemahaman, aplikasi, analisis, evaluasi dan kreativitas. Ranah afektif terbagi menjadi 5 tingkatan yaitu penerimaan, penanggapan, penghargaan, pengorganisasian dan penjatidirian. Ranah psikomotorik terbagi menjadi 4 tingkatan yaitu peniruan, manipulasi, artikulasi dan pengalamiahan.

Istilah Ilmu Pengetahuan Sosial (IPS) Geografi merupakan terjemahan dari (social studies). Ilmu Pengetahuan Sosial (IPS) menurut Nursid Sumaatmajda (1984: 10) diartikan sebagai "ilmu yang mempelajari bidang kehidupan manusia di masyarakat, mempelajari gejala dan masalah sosial yang terjadi dari bagian kehidupan tersebut". Artinya Ilmu Pengetahuan Sosial diartikan sebagai kajian terpadu dari ilmu-ilmu sosial serta untuk mengembangkan potensi kewarganegaraan. Di dalam program sekolah, Ilmu Pengetahuan Sosial dikoordinasikan sebagai bahasan sistematis serta berasal dari beberapa disiplin ilmu antara lain: Antropologi, Arkeologi, Geografi, Ekonomi, Sejarah, Hukum, Filsafat, Ilmu Politik, Psikologi Agama, Sosiologi, dan juga mencakup materi yang sesuai dari Humaniora, matematika serta Ilmu Alam.

IPS Geografi merupakan salah satu mata pelajaran yang diberikan mulai SMP. IPS Geografi mengkaji seperangkat peristiwa, fakta, konsep, dan generalisasi yang berkaitan dengan isu sosial. Pada jenjang SMP mata pelajaran IPS memuat materi Geografi, Sosiologi, dan Ekonomi. Melalui mata pelajaran IPS, peserta didik diarahkan untuk dapat menjadi warga negara Indonesia yang demokratis, dan bertanggung jawab, serta warga dunia yang cinta damai. Mata pelajaran IPS Geografi disusun secara sistematis, komprehensif, dan terpadu dalam proses pembelajaran menuju kedewasaan dan keberhasilan dalam kehidupan di masyarakat. Dengan pendekatan tersebut diharapkan peserta didik akan memperoleh pemahaman yang lebih luas dan mendalam pada bidang

Kirby (1984:5) strategi sesungguhnya merupakan metode untuk menyelesaikan tugastugas, atau secara umum untuk mencapai tujuan. Strategi pembelajaran adalah metode untuk mencapai tujuan pembelajaran. Dick, W., 
Carey, L., \& Carey, J. (2005:189) menjelaskan strategi pembelajaran sebagai satu set materi dan prosedur pembelajaran yang digunakan secara bersama-sama untuk mencapai hasil belajar siswa. David seperti yang dikutip Sanjaya (2008:126) mendefinisikan strategi pembelajaran sebagai perencanaan yang berisi tentang rangkaian kegiatan yang didesain untuk mencapai tujuan pendidikan tertentu.

Prawiradilaga

(2008:37)

mendefinisikan strategi pembelajaran sebagai upaya yang dilakukan oleh perancang dalam menentukan teknik penyampaian pesan, penentuan metode dan media, alur isi pelajaran serta interaksi antara pengajar dan peserta didik. Strategi pembelajaran menurut Miarso (2007:530) merupakan pendekatan menyeluruh pembelajaran dalam suatu sistem pembelajaran, yang berupa pedoman umum dan kerangka kegiatan untuk mencapai tujuan umum pembelajaran, yang dijabarkan dari pandangan falsafah atau teori belajar tertentu.

Menurut Sanjaya (2008:58) suatu proses pembelajaran berhasil mencapai tujuan yang merupakan hasil dari interaksi dan interelasi komponen-komponen yang membentuk sistem pembelajaran. Komponenkomponen tersebut adalah tujuan, materi pelajaran, strategi pembelajaran, media dan evaluasi. Setiap komponen akan mempengaruhi keberhasilan proses pembelajaran dan akan mempengaruhi keberhasilan pencapaian tujuan pembelajaran. Salah satu komponen tersebut adalah strategi pembelajaran. Keberhasilan pencapaian tujuan sangat ditentukan oleh komponen ini. Bagaimanapun lengkap dan jelasnya komponen yang lain, tanpa diimplementasikan melalui strategi yang tepat, maka komponen-komponen yang lain tidak memiliki makna dalam proses pembelajaran dan mengakibatkan tujuan pembelajaran tidak tercapai dengan maksimal dan hasil belajar yang diperoleh tidak memuaskan.

Menurut Sanjaya (2008:131) terdapat prinsip-prinsip umum penggunaan strategi pembelajaran yaitu : (1) berorientasi pada tujuan, yaitu dalam pembelajaran tujuan merupakan komponen yang utama, keberhasilan suatu strategi tergantung pada tercapainya tujuan, (2) aktivitas, strategi pembelajaran harus dapat mendorong aktivitas siswa (3) individualitas, strategi pembelajaran pada hakikatnya ingin mencapai perubahan prilaku setiap siswa dan (4) integritas, strategi pembelajaran harus dapat mengembangkan seluruh aspek kepribadian siswa secara terintegrasi

Banyak pilihan strategi pembelajaran yang dapat digunakan dalam proses pembelajaran. Rowntree seperti yang dikutip Sanjaya (2008:128) mengelompokkan strategi pembelajaran ke dalam strategi pembelajaran penemuan, strategi pembelajaran kelompok dan strategi pembelajaran individual. Dalam strategi penyampaian penemuan bahan pelajaran disajikan dalam bentuk jadi dan siswa dituntut untuk menguasai bahan tersebut. Strategi pembelajaran individual dilakukan oleh siswa secara mandiri. Keberhasilan dan kegagalan sangat ditentukan oleh kemampuan siswa sendiri. Strategi pembelajaran kelompok dilakukan secara beregu dan tidak memperhatikan kecepatan belajar individual.

Strategi pembelajaran berbasis Genius Learning adalah rangkaian pendekatan praktis dalam upaya meningkatkan hasil pembelajaran. Upaya peningkatan ini dicapai dengan menggunakan pengetahuan yang berasal dari berbagai disiplin ilmu seperti pengetahuan tentang tata cara kerja otak, cara kerja memori, neurolinguistik programming, motivasi, gaya belajar, kepribadian, emosi, perasaan, pikiran, metakognisi, multiple intellegence, teknik memori, teknik membaca, teknik mencatat dan teknik belajar lainnya (Gunawan, 2006: 2).

Dasar strategi pembelajaran berbasis Genius Learning adalah Accelerated Learning atau cara belajar yang dipercepat. Tujuannya sama, yaitu bagaimana membuat proses pembelajaran menjadi efisien, efektif, dan menyenangkan. Asumsi dasar yang digunakan dalam mendefinisikan kecerdasan dalam strategi pembelajaran berbasis Genius Learning adalah sebagai berikut :

Pertama, Setiap orang lahir dengan kemampuan yang sama dan unik (Madden, 2002:11). Setiap orang dilahirkan dengan suatu kombinasi kecerdasan yang beragam. Kondisi lingkungan dan proses pembelajaran akan menentukan seberapa cepat atau lambat proses perkembangan kecerdasan ini terjadi. Faktor yang mempengaruhi pertumbuhan dan perkembangan kecerdasan (Gunawan, 2006:223) antara lain, lingkungan, kemauan dan keputusan, pengalaman hidup, genetika, dan gaya hidup.

Strategi pembelajaran berbasis Genius Learning menurut Gunawan (2006:334) terdiri dari tahapan-tahapan berikut: (1) suasana kondusif, (2) hubungkan, (3) gambaran besar, 
(4) tetapkan tujuan, (5) pemasukan informasi, (6) aktivasi, (7) demonstrasi, (8) ulangi dan jangkarkan.

Menurut Walberg dan Greenberg yang dikutip DePorter, (2004:19,374), lingkungan sosial adalah penentu psikologis utama yang mempengaruhi belajar akademis. Suasana atau keadaan ruangan menunjukkan arena belajar yang dipengaruhi emosi. Penelitian menunjukkan bahwa para siswa menyebut kualitas hubungan mereka dengan guru sebagai faktor paling utama dalam kaitannya dengan kenyamanan dalam belajar atau tidak.

Penciptaan lingkungan belajar yang menyenangkan dan pembinaan hubungan yang harmonis antara guru dan siswa diharapkan mampu memunculkan emosi yang positif bagi siswa. Emosi yang positif ini sangat mempengaruhi keberhasilan siswa dalam belajar, karena berkaitan dengan cara kerja otak manusia yaitu sistem limbik. Sistem limbik berkaitan erat dengan emosi dan memori jangka panjang. Sistem limbik di dalam otak mamalia berperan sebagai saklar yang menentukan otak mana yang aktif, otak reptil (pusat kendali, mengatur fungsi utama tubuh, insting, mengatur reaksi dalam keadaan bahaya) atau otak neo cortex (proses berpikir). Seseorang yang berada dalam keadaan tegang, stres, takut atau marah, akan meneruskan informasi yang diterima ke otak reptil, sehingga otak neo cortex tidak mampu berfikir. Sebaliknya, ketika seseorang dalam keadaan bahagia, tenang, dan rileks, maka otak neo cortex akan aktif dan akan digunakan untuk berfikir (Gunawan, 2004:24).

Lingkungan yang banyak memberikan tekanan mental dan stres akan sangat menghambat kinerja otak, sehingga siswa akan kesulitan untuk menyerap informasi yang disampaikan oleh guru selama proses belajar mengajar. Goleman berpendapat, "Seseorang dapat berkonsentrasi paling baik saat mereka sedikit lebih dituntut dari biasanya, dan mereka dapat memberikan lebih dari biasanya. Jika tuntutan terlalu sedikit, orang akan menjadi bosan, jika tuntutan terlalu besar untuk diatasi, mereka akan menjadi cemas." (DePorter, 2004:23). Oleh karena itu, menjadi sangat penting bagi seorang guru untuk dapat menciptakan kondisi fisik maupun mental yang nyaman dan mendukung untuk melakukan aktivitas belajar bagi siswa.

Strategi pembelajaran Ekspositori merupakan strategi memberitahukan atau menjelaskan (Jarolimek \& Foster, 1976:94).
Dalam strategi pembelajaran Ekspositori guru menjadi sumber informasi utama, namun sumber data dan infromasi lain juga dapat digunakan. Sumber informasi yang paling sering dipakai adalah buku teks. Sumber lain seperti gambar, filmstrip, ensiklopedi, perpustakaan juga sering digunakan dalam strategi pembelajaran Ekspositori.

Strategi pembelajaran Ekspositori menurut Sanjaya (2008:179) adalah strategi pembelajaran yang menekankan pada proses penyampaian materi secara verbal dari seorang guru kepada sekelompok siswa dengan maksud agar siswa dapat menguasai materi pelajaran secara optimal.

Strategi pembelajaran Ekspositori sering dihubungkan dengan kurangnya latihan dalam pembelajaran, menggunakan buku secara monoton, kekakuan, penekanan pada pembelajaran berdasarkan fakta dan hafalan, menggunakan metode ceramah, dan lain-lain. Manson dan Williams seperti yang dikutip Jarolimek \& Foster (1976:95) menjelaskan, pembelajaran yang berbasis pada siswa secara umum diajukan sebagai antitesis strategi pembelajaran Ekspositori di mana pembelajar menjadi penerima pengetahuan. Strategi pembelajaran ekpositori lebih cocok digunakan untuk mentransfer pengetahuan.

Karakteristik siswa sebagai individu yang unik juga mempengaruhi hasil belajar. Uno (2006:143) mengungkapkan bahwa karakteristik siswa merupakan salah satu hal yang perlu diidentifikasi oleh guru untuk digunakan sebagai petunjuk dalam mengembangkan program pembelajaran.

Memperhatikan pada bagan pada gambar 1 (hal.21), yang menjelaskan hubungan antara variabel kondisi, metode dan hasil dikembangkan Reigeluth (1983), maka akan terlihat bahwa salah satu variabel kondisi yang mempengaruhi hasil belajar siswa adalah karakteristik siswa. Karakteristik yang diidentifikasi dapat berupa bakat, motivasi, gaya belajar, kemampuan berfikir, minat sikap, kemampuan awal, kecerdasan dan sebagainya.

Karakteristik siswa yang banyak dikaji oleh para ahli dan dikelompokkan berdasarkan sudut pandang yang berbeda-beda adalah gaya belajar. Cullingford (1995:110) menyatakan "pengetahuan tentang karakteritik siswa yang paling membantu seorang guru dalam memahami siswa adalah gaya belajar". 
Dunn dan Dunn, seperti yang dikutip Prashnig (2007:31), mengungkapkan bahwa gaya belajar adalah cara manusia mulai berkonsentrasi, menyerap, memproses, dan menampung informasi yang baru dan sulit. Pask seperti yang dikutip Marjoribanks (1991:142) menjelaskan gaya belajar sebagai pengetahuan tentang belajar yang dikaitkan dengan strategi yang konsisten yang dilakukan seseorang dalam belajar. Dengan definisi yang hampir serupa Kemp (1977:21) menjelaskan gaya belajar sebagai cara yang lebih menyenangkan dan efektif bagi seseorang untuk belajar. Charles (1980:64) mendefenisikan gaya belajar dengan lebih sederhana yaitu pendekatan yang digunakan seseorang dalam belajar. Dengan merepresentasikan makna dari definisi-definisi sebelumnya, Nasution (2008:94) mendefinisikan gaya belajar sebagai cara yang konsisten yang dilakukan siswa dalam menangkap stimulus atau informasi, cara mengingat, cara berfikir dan memecahkan soal.

David A. Kolb adalah salah seorang ahli yang mengemukakan teori tentang gaya belajar yang dikembangkannya berdasarkan teori belajarnya yaitu Experiential Learning. Kolb membagi gaya belajar dalam empat tipe yaitu Konvergen, Divergen, Asimilator dan Akomodator.

Pada tahun 1984 Kolb mengemukakan teorinya tentang belajar dan gaya belajar. Kolb (1984:41) memandang belajar sebagai proses dimana pengetahuan dibentuk melalui transformasi pengalaman. Pengetahuan dihasilkan dari kombinasi pengalaman yang diperoleh dan merubahnya. Kolb berpendapat bahwa pembelajaran pengalaman mempunyai enam karakteristik penting yaitu, (1) belajar dipahami sebagai proses, bukan hasil, (2) belajar adalah proses yang kontinu berdasarkan dari pengalaman, (3) belajar membutuhkan resolusi dari konflik antara model yang dipertentangkan dari adaptasi, (4) belajar adalah proses holistik dari adaptasi, (5) belajar meliputi transaksi antara manusia dan lingkungannya dan (6) belajar adalah proses membentuk pengetahuan yang dihasilkan dari transaksi antara pengetahuan sosial dan pengetahuan pribadi.

Gaya belajar Kolb didasarkan atas psikologi Jung (Nasution, 2008:111). Menurut Kolb belajar berlangsung melalui empat tahapan yaitu (1) individu memperoleh pengalaman langsung yang konkret, (2) mengembangkan observasi, memikirkan dan merefleksikan, (3) membentuk generalisasi dan abstraksi dan (4) mengambil implikasi dari konsep-konsep yang dijadikan sebagai pegangan dalam menghadapi hal-hal baru.

Kolb mengemukakan adanya empat kutub kecenderungan seseorang dalam proses belajar seperti pada gambar 3, kutub-kutub tersebut yaitu : (1) kutub perasaan/feeling (Concrete Experience), (2) kutub Pemikiran/thinking conceptualization), (abstract kutub pengamatan/watching (reflective observation) dan (4) kutub tindakan/doing (active experimentation).

Muijs \& Reynolds (2008:306) menyatakan tipe pelajar dengan gaya belajar Divergen menikmati belajar yang self-directed, belajar mandiri, simulasi dan bermain peran. Bidang pekerjaan yang sesuai dengan tipe gaya belajar ini adalah praktisi-praktisi disiplindisiplin yang kreatif, seperti seniman, konseling, personalia dan pengembangan organisasi.

Tabel 1. Perbedaan Strategi pembelajaran berbasis Genius Learning dan strategi pembelajaran Ekpositori

\begin{tabular}{|l|l|l|}
\hline \multicolumn{1}{|c|}{ Aspek } & \multicolumn{1}{|c|}{ Genius Learning } & \multicolumn{1}{c|}{ Ekspositori } \\
\hline Pendekatan & Berorientasi pada siswa & Berorientasi pada guru \\
\hline Aktivitas & Aktivitas belajar bervariasi & Aktivitas belajar kurang bervariasi \\
\hline Metode & $\begin{array}{l}\text { Metode mengajar mengakomodasikan } \\
\text { gaya belajar secara seimbang }\end{array}$ & $\begin{array}{l}\text { Metode mengajar tidak } \\
\text { mengakomodasikan gaya belajar siswa } \\
\text { secara seimbang }\end{array}$ \\
\hline $\begin{array}{l}\text { Pemberian } \\
\text { latihan }\end{array}$ & $\begin{array}{l}\text { Mengedepankan pengulangan dan } \\
\text { umpan balik yang segera serta } \\
\text { memberikan tugas yang bervariasi } \\
\text { yang mengakomodasikan kecerdasan } \\
\text { ganda }\end{array}$ & $\begin{array}{l}\text { Tidak banyak melakukan pengulangan } \\
\text { dan memberikan tugas yang cenderung } \\
\text { hanya menuntut kemampuan hafalan } \\
\text { siswa }\end{array}$ \\
\hline $\begin{array}{l}\text { Sumber } \\
\text { belajar }\end{array}$ & $\begin{array}{l}\text { Menggunakan sumber belajar yang } \\
\text { lebih bervariasi }\end{array}$ & $\begin{array}{l}\text { Sumber belajar cenderung monoton dan } \\
\text { kurang bervariasi }\end{array}$ \\
\hline
\end{tabular}




\begin{tabular}{|c|c|c|}
\hline $\begin{array}{l}\text { Suasana } \\
\text { kelas }\end{array}$ & $\begin{array}{l}\text { Suasana kelas yang menyenangkan } \\
\text { dengan diiringi musik akan membuat } \\
\text { siswa merasa nyaman belajar }\end{array}$ & $\begin{array}{l}\text { Suasana kelas cenderung monoton, } \\
\text { tenang, tidak banyak melakukan } \\
\text { aktivitas selain mendengarkan } \\
\text { penjelasan guru dan tanya jawab }\end{array}$ \\
\hline Waktu & $\begin{array}{l}\text { Aktivitas belajar yang banyak menyita } \\
\text { waktu lebih banyak }\end{array}$ & $\begin{array}{l}\text { Aktivitas belajar yang tidak terlalu } \\
\text { banyak membutuhkan lebih sedikit } \\
\text { waktu }\end{array}$ \\
\hline $\begin{array}{l}\text { Tahapan } \\
\text { pelaksanaan }\end{array}$ & $\begin{array}{ll}\text { 1. } & \text { Suasana kondusif } \\
\text { 2. } & \text { Menghubungkan } \\
\text { 3. } & \text { Gambaran besar } \\
\text { 4. } & \text { Menetapkan tujuan } \\
\text { 5. } & \text { Pemasukan informasi } \\
\text { 6. } & \text { Aktivasi } \\
\text { 7. } & \text { Demontrasi } \\
\text { 8. } & \text { Tinjau ulang dan jangkarkan } \\
\end{array}$ & $\begin{array}{ll}\text { 1. } & \text { Persiapan } \\
\text { 2. } & \text { Penyajian } \\
\text { 3. } & \text { Korelasi } \\
\text { 4. } & \text { Menyimpulkan } \\
\text { 5. } & \text { Mengaplikasikan }\end{array}$ \\
\hline
\end{tabular}

Rumuskan masalah sebagai berikut: (1) Apakah hasil belajar IPS Geografi siswa yang diajar dengan strategi pembelajaran berbasis Genius Learning lebih tinggi daripada hasil belajar IPS Geografi siswa yang diajar dengan strategi pembelajaran Ekspositori?; (2) Apakah hasil belajar IPS Geografi siswa yang memiliki gaya belajar konvergen lebih tinggi daripada hasil belajar IPS Geografi siswa yang memiliki gaya belajar divergen?; dan (3) Apakah terdapat interaksi antara strategi pembelajaran dengan gaya belajar dalam mempengaruhi hasil belajar IPS Geografi siswa?

\section{METODE}

Penelitian ini dilaksanakan di SMP Negeri 1 Pangururan Kabupaten Samosir. Populasi adalah seluruh siswa kelas VII SMP Negeri 1 Pangururan Kabupaten Samosir dengan jumlah seluruh siswa 172 orang. Setiap kelas memiliki karakteristik yang sama, artinya setiap kelas tidak memiliki siswa yang pernah tinggal kelas, siswa rata-rata memiliki umur yang tidak jauh berbeda, diajar oleh guru yang sama dan menggunakan kurikulum yang sama.

Teknik pengambilan sampel acak sederhana (random sampling) adalah yang paling baik, namun dalam penelitian ini karena kondisi populasi sudah dikelompokkelompokkan dan tidak memungkinkan untuk diubah maka sampel dipilih dengan teknik cluster random sampling (sampel acak kelompok).

Penelitian ini menggunakan metode eksperimen dengan rancangan quasi eksperimen disain faktorial $2 \times 2$. Melalui disain ini akan dibandingkan pengaruh strategi pembelajaran berbasis Genius Learning dan strategi pembelajaran Ekspositori. Strategi pembelajaran berbasis Genius Learning dan strategi pembelajaran Ekspositori diperlakukan kepada kedua kelompok eksperimen yang masing-masing kelompok terdiri dari siswasiswa dengan gaya belajar yang berbeda-beda. Strategi pembelajaran berbasis Genius Learning dan strategi pembelajaran Ekspositori sebagai variabel bebas. Gaya belajar sebagai variabel moderator dan hasil belajar IPS Geografi sebagai variabel terikat. Variabel-variabel tersebut tersebut selanjutnya akan ditinjau dalam penelitian dengan disain seperti terlihat dalam Tabel 2 sebagai berikut:

Tabel 2. Desain eksperimen faktorial 2 x 2

\begin{tabular}{|c|c|c|}
\hline Strategi Pembelajaran(A) & Genius Learning $\left(\mathrm{A}_{1}\right)$ & Ekspositori $\left(\mathrm{A}_{2}\right)$ \\
\hline Gaya belajar $(\mathrm{B})$ & & \\
\hline & $\mathrm{A}_{1} \mathrm{~B}_{1}$ & $\mathrm{~A}_{2} \mathrm{~B}_{1}$ \\
\hline Konvergen $\left(\mathrm{B}_{1}\right)$ & $\mathrm{A}_{1} \mathrm{~B}_{2}$ & $\mathrm{~A}_{2} \mathrm{~B}_{2}$ \\
\hline Divergen $\left(\mathrm{B}_{2}\right)$ & & \\
\hline
\end{tabular}

Keterangan :

$A_{1} B_{1}$ : Hasil belajar IPS siswa yang yang diajar dengan strategi pembelajaran berbasis
Genius Learning yang memiliki gaya belajar konvergen 
$\mathrm{A}_{1} \mathrm{~B}_{2}$ : Hasil belajar IPS siswa yang diajar dengan strategi pembelajaran berbasis Genius Learning yang memiliki gaya belajar divergen

$\mathrm{A}_{2} \mathrm{~B}_{1}$ : Hasil belajar IPS siswa yang dibelajarkan dengan strategi pembelajaran Ekspositori yang memiliki gaya belajar konvergen

$\mathrm{A}_{2} \mathrm{~B}_{2}$ : Hasil belajar IPS siswa yang dibelajarkan dengan strategi pembelajaran Eskpositori yang memiliki gaya belajar divergen

Teknik analisa data yang digunakan adalah teknik statistik inferensial dan deskriptif. Teknik statistik inferensial digunakan untuk menguji hipotesis penelitian, dimana teknik inferensial yang digunakan adalah teknik analisis varians dua jalur dengan taraf signifikan 0,05. Sebelum teknik ini digunakan perlu dilakukan uji persyaratan. Uji persyaratan yang dilakukan adalah uji normalitas menggunakan uji Lilliefors (Sudjana, 2002:466) dan uji homogenitas menggunakan uji $\mathrm{F}$, dan uji Bartlett (Sudjana, 2002:261). Bila pengujian hipotesis ternyata interaksi antara strategi pembelajaran dengan dengan gaya belajar terhadap hasil belajar IPS Geografi signifikan, maka dilakukan uji lanjut dengan menggunakan Uji Scheffe bila banyak data dalam setiap sel berbeda. Bila banyak data setiap sel sama maka dipergunakan Uji Tukey. Untuk keperluan pengujian hipotesis, dirumuskan hipotesis statistik penelitian sebagai berikut:

Hipotesis Pertama

$\mathrm{H}_{\mathrm{o}}: \mu \mathrm{A}_{1}=\mu \mathrm{A}_{2}$

$\mathrm{H}_{\mathrm{a}}: \mu \mathrm{A}_{1}>\mu \mathrm{A}_{2}$

Hipotesis Kedua

$\mathrm{H}_{\mathrm{o}}: \mu \mathrm{B}_{1}=\mu \mathrm{B}_{2}$

$\mathrm{H}_{\mathrm{a}}: \mu \mathrm{B}_{1}>\mu \mathrm{B}_{2}$

Hipotesis Ketiga

$\mathrm{H}_{\mathrm{o}}: \mathrm{A}><\mathrm{B}=0$

$\mathrm{H}_{\mathrm{a}}: \mathrm{A}><\mathrm{B} \neq 0$

\section{HASIL DAN PEMBAHASAN \\ Hasil}

Sebelum melakukan pengujian hipotesis terlebih dahulu menghitung total skor dan rata-rata skor tiap kelompok perlakuan seperti tabel 3 , yang selanjutnya dapat digunakan sebagai dasar keputusan statistik untuk pengujian hipotesis, seperti pada sebagai berikut.

Tabel 3. Data Induk Penelitian

\begin{tabular}{|c|c|c|c|c|}
\hline \multirow{2}{*}{\multicolumn{2}{|c|}{ Gaya Belajar }} & \multicolumn{2}{|c|}{ Strategi Pembelajaran } & \multirow{2}{*}{ TOTAL } \\
\hline & & Genius learning & Ekspositori & \\
\hline \multirow{5}{*}{ Konvergen } & $\mathrm{N}$ & 18 & 19 & 37 \\
\hline & $\sum X$ & 1567 & 1470 & 3037 \\
\hline & $\sum X^{2}$ & 137255 & 116048 & 253303 \\
\hline & $\bar{X}$ & 89.20 & 77.00 & 83.10 \\
\hline & $S^{2}$ & 34.34 & 124.00 & 79.17 \\
\hline \multirow{5}{*}{ Divergen } & $\mathrm{N}$ & 15 & 13 & 28 \\
\hline & $\sum X$ & 1331 & 1151 & 2482 \\
\hline & $\sum X^{2}$ & 118881 & 102181 & 221062 \\
\hline & $\bar{X}$ & 86.67 & 86.96 & 86.82 \\
\hline & $\mathrm{S}^{2}$ & 64.47 & 10.27 & 37.37 \\
\hline \multirow{5}{*}{ TOTAL } & $\mathrm{N}$ & 33 & 32 & 65 \\
\hline & $\sum X$ & 2898 & 2621 & 5519 \\
\hline & $\sum X^{2}$ & 256136 & 218229 & 474365 \\
\hline & $X$ & 87.94 & 81.98 & 84.96 \\
\hline & $S^{2}$ & 49.41 & 67.14 & 58.27 \\
\hline
\end{tabular}

Secara keseluruhan hasil perhitungan Anava untuk pengujian hipotesis dapat diketahui melalui Tabel 4 berikut. 
Tabel 4. Rangkuman Hasil Perhitungan ANAVA Faktorial 2 x 2

\begin{tabular}{|l|r|l|l|r|r|l|}
\hline Sumber Varians & \multicolumn{1}{|l|}{ dk } & \multicolumn{1}{l|}{ JK } & \multicolumn{1}{l|}{ RJK } & \multicolumn{1}{|l|}{ Fhitung } & $\mathbf{F}_{\text {tabel }}$ & Keterangan \\
\hline Strategi & & & & & & Signifikan \\
Pembelajaran & 1 & 686.26 & 686.2608 & 9.96 & 3.98 & \\
\hline Gaya Belajar & 1 & 567.82 & 567.82 & 8.24 & & Signifikan \\
\hline Interaksi (AxB) & 1 & 299.84 & 299.84 & 4.35 & & Signifikan \\
\hline Antar Kelompok & 3 & 1553.92 & & & & \\
\hline Galat & 61 & 4205.09 & 68.94 & & & \\
\hline TOTAL & 67 & & & & & \\
\hline
\end{tabular}

Karena ada interaksi antara strategi pembelajaran dan gaya belajar dalam mempengaruhi hasil belajar IPS Geografi , maka perlu dilakukan uji lanjutan (post hoc test), untuk mengetahui rata-rata hasil belajar sampel mana yang berbeda. Untuk melihat bentuk interaksi antara strategi pembelajaran dan gaya belajar dalam mempengaruhi hasil belajar IPS Geografi dilakukan uji lanjut dengan menggunakan Uji Scheffe. Hasil perhitungan menggunakan Uji Scheffe dapat dikemukakan melalui ringkasan pada Tabel 5 berikut.

Tabel 5. Ringkasan Hasil Perhitungan Uji Scheffe

\begin{tabular}{|c|c|c|c|}
\hline No & Interaksi & Fhitung & $\mathbf{F}_{\text {tabel }}(\boldsymbol{\alpha}=\mathbf{0 , 0 5})$ \\
\hline 1 & $\mu \mathrm{A}_{1} \mathrm{~B}_{1}$ dengan $\mu \mathrm{A}_{2} \mathrm{~B}_{1}$ & 3,5398 & 2,72 \\
\hline 2 & $\mu \mathrm{A}_{1} \mathrm{~B}_{1}$ dengan $\mu \mathrm{A}_{2} \mathrm{~B}_{2}$ & 0,5559 & 2,72 \\
\hline 3 & $\mu \mathrm{A}_{1} \mathrm{~B}_{1}$ dengan $\mu \mathrm{A}_{1} \mathrm{~B}_{2}$ & 0,6890 & 2,72 \\
\hline 4 & $\mu \mathrm{A}_{1} \mathrm{~B}_{2}$ dengan $\mu \mathrm{A}_{2} \mathrm{~B}_{1}$ & 4,0682 & 2,72 \\
\hline 5 & $\mu \mathrm{A}_{1} \mathrm{~B}_{2}$ dengan $\mu \mathrm{A}_{2} \mathrm{~B}_{2}$ & 0,1019 & 2,72 \\
\hline 6 & $\mu \mathrm{A}_{2} \mathrm{~B}_{2}$ dengan $\mu \mathrm{A}_{2} \mathrm{~B}_{1}$ & 3,7969 & 2,72 \\
\hline
\end{tabular}

Untuk melihat dengan jelas strategi Anava yang menunjukkan adanya interaksi antara penggunaan strategi pembelajaran dan gaya belajar dalam mempengaruhi hasil belajar IPS Geografi dapat ditunjukkan melalui gambar 1 berikut.

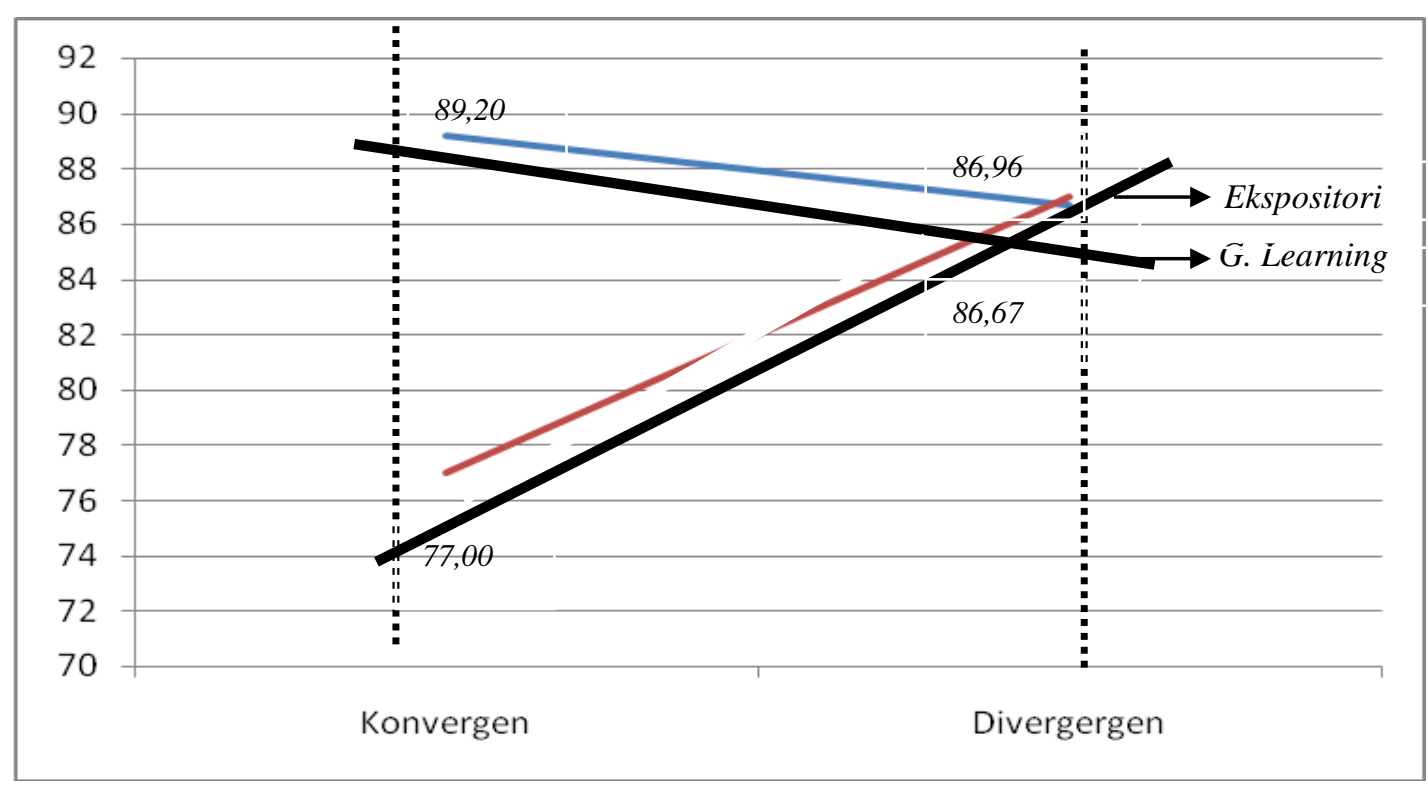


Gambar 1. Pola Garis Interaksi antara Strategi Pembelajaran dan Gaya Belajar Terhadap Hasil Belajar IPS Geografi Siswa

\section{Pembahasan}

Selain sifat dari materi pelajaran, salah satu dasar pemikiran lain yang digunakan oleh guru sebagai pertimbangan dalam merancang strategi pembelajaran adalah karakteristik siswa. Uno (2006:143) mengungkapkan bahwa karakteristik siswa merupakan salah satu hal yang perlu diidentifikasi oleh guru untuk digunakan sebagai petunjuk dalam mengembangkan program pembelajaran. Setiap siswa memiliki potensi dan karakteristik yang berbeda-beda. Seorang guru harus berusaha mengakomodir potensi siswa secara maksimal dalam strategi pembelajaran yang diterapkan di kelas. Karakteristik siswa seperti motivasi, minat, bakat, kecerdasan, gaya belajar, kepribadian, emosi, perasaan, pikiran, dan metakognisi perlu dipertimbangkan dan diintegrasikan dalam strategi pembelajaran yang dirancang.

Jika melihat pertimbangan dalam pemilihan strategi pembelajaran berdasarkan sifat materi dan karakteristik siswa, maka strategi pembelajaran berbasis Genius Learning merupakan salah satu strategi pembelajaran yang dapat dipilih dalam pelajaran IPS Geografi. Strategi pembelajaran berbasis Genius Learning mencoba memaksimalkan dan mengakomodir potensi-potensi yang ada dalam diri siswa, sehingga menjadi strategi pembelajaran yang memiliki banyak variasi metode pembelajaran di dalamnya. Hal ini menjadikan strategi pembelajaran berbasis Genius Learning mampu menciptakan suasana yang menyenangkan sehingga memotivasi siswa belajar.

Strategi pembelajaran berbasis Genius Learning merupakan rangkaian pendekatan praktis dalam upaya meningkatkan hasil pembelajaran. Upaya peningkatan ini dicapai dengan menggunakan pengetahuan yang berasal dari berbagai disiplin ilmu seperti pengetahuan tentang tata cara kerja otak, cara kerja memori, neurolinguistik programming, motivasi, gaya belajar, kepribadian, emosi, perasaan, pikiran, metakognisi, gaya belajar, multiple intellegence, teknik memori, teknik membaca, teknik mencatat dan teknik belajar lainnya (Gunawan, 2006: 2). Tujuannya dari strategi pembelajaran berbasis Genius Learning, yaitu bagaimana membuat proses pembelajaran menjadi efisien, efektif, dan menyenangkan.

Selain strategi pembelajaran berbasis Genius Learning, strategi pembelajaran yang dieksperimenkan dalam penelitian ini adalah strategi Ekspositori. Strategi pembelajaran Ekspositori merupakan strategi memberitahukan atau menjelaskan (Jarolimek \& Foster, 1976:94). Dalam strategi pembelajaran Ekspositori guru menjadi sumber informasi utama, namun sumber data dan infromasi lain juga dapat digunakan.

Strategi pembelajaran berbasis Genius Learning dan strategi pembelajaran Ekspositori memberikan pengaruh yang berbeda terhadap hasil belajar. Hal ini disebabkan kedua strategi ini memiliki pendekatan dan prosedur yang berbeda dalam pelaksanaannya. Strategi pembelajaran Genius Learning pada dasarnya merupakan strategi pembelajaran yang didasari cara belajar cepat (Accelerated Learning). Berbagai pendekatan digunakan untuk membentuk suatu rangkaian kegiatan pembelajaran, seperti tata cara kerja otak, cara kerja memori, neurolinguistik programming, motivasi, gaya belajar, kepribadian, emosi, perasaan, pikiran, metakognisi, gaya belajar, multiple intellegence, teknik memori, teknik membaca, teknik mencatat dan teknik belajar lainnya. Sedangkan strategi pembelajaran Ekspositori adalah strategi pembelajaran yang menekankan pada proses penyampaian materi secara verbal dari seorang guru kepada sekelompok siswa dengan maksud agar siswa dapat menguasai materi pelajaran secara optimal. 
Dilihat dari segi pendekatan yang digunakan Strategi pembelajaran berbasis Genius Learning menggunakan pendekatan yang berorientasi pada siswa. Strategi pembelajaran berbasis Genius Learning berupaya mengoptimalkan potensi yang dimiliki oleh siswa sekaligus menghargai perbedaan masing-masing siswa sebagai individu yang unik. Setiap siswa memiliki potensi yang berbeda-beda sekaligus memiliki kemampuan yang luar biasa untuk mengolah informasi jika saja digunakan metode yang tepat untuk membantu mereka belajar.

Strategi pembelajaran berbasis Genius Learning mencoba menciptakan suasana menyenangkan ketika belajar sekaligus melibatkan setiap siswa di dalam kelas untuk terlibat dalam setiap kegiatan kelas yang dilakukan. Hal ini membuat siswa mau tidak mau harus terlibat dan memfokuskan perhatiannya pada pelajaran. Siswa menjadi lebih termotivasi dan tidak merasa bosan selama mengikuti pelajaran.

Dari segi aktivitas guru dan siswa, strategi pembelajaran berbasis Genius Learning sama-sama melibatkan guru dan siswa dalam pembelajaran. Akan tetapi, siswa mendapatkan porsi yang lebih besar. Guru berperan sebagai pembimbing dan motivator agar siswa mau belajar dan aktif di kelas. Guru merancang aktivitas belajar yang banyak melibatkan peran serta siswa seperti senam otak, menulis kartu goal setting bersama-sama, membuat lirik lagu, permainan, demonstrasi di depan kelas, role playing dan banyak aktivitas lainnya. Semua aktivitas ini dilakukan dalam upaya menciptakan lingkungan belajar yang menyenangkan bagi siswa dan membina hubungan positif untuk menghilangkan kecemasan dan meningkatkan motivasi belajar siswa.

Dalam mempelajari IPS Geografi sangat dibutuhkan variasi aktivitas kelas sehingga tidak membuat siswa bosan. Dengan beragam aktivitas siswa merasa nyaman dan membangun pikiran positif sehingga tidak menganggap IPS Geografi sebagai pelajaran yang membosankan. Aktivitas yang beragam dalam strategi pembelajaran berbasis Genius Learning seperti, aktivasi, demonstrasi, permainan, role playing, senam otak akan meningkatkan keterlibatan siswa dalam proses pembelajaran dan menjaga agar siswa tetap berkonsentrasi mengikuti pelajaran. IPS Geografi akan lebih mudah dipahami jika siswa melakukan dan membuktikan gejala-gejala alam dalam kehidupan sehari-hari kemudian menganalisanya.

Dari segi suasana kelas ketika proses pembelajaran, inti dari Strategi pembelajaran berbasis Genius Learning adalah menciptakan suasana yang menyenangkan untuk belajar sehingga siswa merasa nyaman untuk belajar dan lebih mudah menyerap informasi. Dalam strategi pembelajaran berbasis Genius Learning guru mencoba menciptakan suasana kelas yang menyenangkan misalnya dengan melakukan senam otak sebelum belajar, mengiringi pembelajaran dengan musik, menata ruangan menjadi lebih rapi dan apik dengan tempelantempelan gambar edukatif dan afirmasi positif.

Sedangkan dalam kelas Ekspositori kelas ditata dengan suasana formal dan situasi belajar cenderung kaku. Hal ini akan membuat siswa bosan dan suasana belajar menjadi tidak menyenangkan. Suasana kelas yang menyenangkan diharapkan akan lebih memotivasi siswa untuk belajar, mudah menangkap dan mencerna informasi yang dipelajari serta meningkatkan hasil belajarnya.

Dilihat dari segi prosedur strategi pembelajaran berbasis Genius Learning terdiri dari delapan tahapan yang terdiri dari suasana kondusif, hubungkan, gambaran besar, tetapkan tujuan, pemasukan informasi, aktivasi, demonstrasi serta tinjau ulang dan jangkarkan. Kedelapan tahapan tersebut dapat dibagi menjadi 3 bagian besar, yaitu pembuka (suasana kondusif, hubungkan, gambaran besar dan tetapkan tujuan), isi (pemasukan informasi) dan penutup (aktivasi, demonstrasi serta tinjau ulang dan jangkarkan). 
Seperti yang telah dijelaskan sebelumnya, selain faktor dari luar diri siswa seperti strategi pembelajaran faktor dari dalam diri siswa seperti kecerdasan, motivasi dan bakat, juga mempengaruhi hasil belajar yang akan diperolehnya. Salah satu karakteristik siswa yang banyak dikaji oleh para ahli dan dikelompokkan berdasarkan sudut pandang yang berbedabeda adalah gaya belajar. Cullingford (1995:110) menyatakan bahwa pengetahuan tentang karakteritik siswa yang paling membantu seorang guru dalam memahami siswa adalah gaya belajar.

Secara teoretis, argumen tentang pentingnya memahami gaya belajar peserta didik untuk mencapai hasil belajar yang optimal sudah menjadi simpulan utama. Masing-masing individu, termasuk peserta didik, memiliki gaya belajar berbeda. Individu dengan IQ yang sama, kecakapan yang sama, dan kemampuan memproses informasi yang sama, dalam banyak hal akan berbeda dari cara mereka menerima sesuatu, cara berfikir, menyelesaikan berbagai persoalan, dan mengingat sesuatu.

Siswa dengan tipe gaya belajar konvergen merupakan gabungan dari kutub konseptualisasi abstrak dan kutub eksperimentasi aktif. Artinya, siswa memiliki kecenderungan belajar dengan menggunakan intelektulitas dan perbuatan mencoba-coba melalui pengalaman praktis. Siswa dengan dominasi gaya belajar Konvergen belajar dengan cara berfikir dan berbuat. Mereka belajar dengan melakukan sesuatu dan mengalami sendiri pengalaman belajarnya. Selain itu, mereka juga mengambil keputusan dengan cerdas dengan menggunakan intelektualitas mereka bukan berdasarkan intuisi atau perasaan. Siswa dengan gaya belajar Konvergen cenderung tidak menyukai pengajaran yang semata-mata teoritis. Mereka memang suka berpikir teoritis akan tetapi mereka juga membutuhkan pengalaman praktis. Mereka lebih mudah menyerap pelajaran jika teori dan praktek berjalan seimbang.

Siswa dengan tipe belajar konvergen sangat mudah penasaran. Mereka suka menguji solusi dengan praktik langsung dan cerdas dalam menentukan sasaran serta menentukan prioritasnya. Namun di samping itu, siswa dengan gaya belajar konvergen sering tidak sabar, mudah bereaksi, lebih berorientasi kepada diri sendiri daripada orang-orang disekitarnya dan tidak senang dengan alternatifalternatif.

Berbeda dengan siswa tipe gaya belajar konvergen, siswa dengan tipe gaya belajar divergen merupakan kombinasi dari kutub pengalaman konkret dan kutub reflektif observasi. Artinya, siswa dengan tipe gaya belajar divergen cenderung lebih nyaman belajar dengan mengamati dan menggunakan perasaan. Mereka belajar dengan perasaan dan pengamatan. Pendekatan yang mereka gunakan pada setiap situasi adalah mengamati bukan bertindak, memutuskan dengan intuisi, perasaan dan sensivitas bukan dengan intelektualitas. Mereka lebih suka belajar dengan mengamati contoh yang didemonstrasikan oleh guru dan mereka lebih terfokus pada hal-hal yang erat kaitannya dengan emosi seperti keindahan gerak dan suasana.

Siswa dengan gaya belajar Divergen adalah siswa yang cenderung tidak suka bertindak. Mereka tidak suka melakukan dan mencoba-coba pengalaman praktis dalam memahami sesuatu tetapi cenderung hanya mengamati pelajaran. Selain itu, dalam membuat kesimpulan dan keputusan mereka cenderung tidak menggunakan analisa logis, tetapi berdasarkan intuisi dan dorongan hati.

Strategi pembelajaran berbasis Genius Learning mengakomodasi lebih banyak potensi yang dimiliki oleh siswa dengan tipe ini. Di dalam strategi pembelajaran berbasis Genius Learning siswa banyak dilibatkan dalam aktivitas kelas, seperti senam otak, membuat kartu goal setting, membuat peta pikiran, bermain peran, simulasi, tugas aktiviasi dan demoanstrasi. Mereka dengan tipe gaya belajar konvergen menjadi lebih tertantang, bersemangat dan termotivasi untuk mengikuti pelajaran. Banyak aktivitas yang 
melibatkan mereka sehingga mereka tidak merasa bosan.

Sebaliknya siswa dengan tipe ini akan merasa bosan dengan strategi pembelajaran ekspositori yang sangat didominasi oleh guru. Siswa lebih banyak mendengarkan dan tidak banyak aktivitas kelas yang membangkitkan semangat siswa. Mereka tidak tertantang untuk melakukan sesuatu. Sifat mereka yang mudah penasaran, dan ingin mencoba sesuatu kurang terakomodasi di strategi pembelajaran ekspositori. Sehingga siswa menjadi bosan dan tidak antusias mengikuti pelajaran. Oleh karena itu, dapat disimpulkan bahwa tipe konvergen akan memperoleh hasil belajar IPS Geografi yang lebih tinggi jika diajar dengan strategi pembelajaran berbasis Genius Learning dibandingkan strategi pembelajaran Ekspositori.

\section{PENUTUP \\ Simpulan}

Simpulan hasil penelitian ini adalah sebagai berikut:

1. Hasil belajar IPS Geografi siswa yang diajar dengan strategi pembelajaran berbasis Genius Learning lebih tinggi dibandingkan siswa yang diajar dengan strategi pembelajaran ekspositori.

2. Hasil belajar IPS Geografi siswa yang memiliki gaya belajar divergen lebih tinggi dibandingkan siswa yang memiliki gaya belajar konvergen.

3. Terdapat interaksi antara strategi pembelajaran berbasis Genius Learning dan gaya belajar dalam mempengaruhi hasil belajar IPS Geografi. Interaksi hanya terlihat untuk gaya belajar konvergen dan Divergen. Siswa dengan gaya belajar Konvergen memperoleh hasil belajar yang lebih tinggi jika diajar dengan strategi pembelajaran berbasis Genius Learning.

\section{Saran}

Berdasarkan hasil penelitian, simpulan, dan keterbatasan penelitian, maka dikemukakan saran-saran sebagai berikut:

1. Guru perlu memperhatikan karakteristik materi pelajaran yang akan disampaikan dalam merancang strategi pembelajaran yang akan diterapkan di kelas.
2. Guru perlu memperhatikan karakteristik siswa, karena gaya belajar yang merupakan aspek kognitif memberikan pengaruh yang besar terhadap hasil belajar siswa.

3. Dikarenakan tes hasil belajar yang disusun hanya mengukur ranah kognitif, disarankan penelitian lanjutan juga mengukur ranah psikomotorik dan afektif.

4. Karakteristik siswa yang dijadikan variabel moderator dalam penelitian ini adalah gaya belajar oleh karena itu, disarankan untuk penelitian lanjut, melibatkan karakteristik siswa yang lain guna melengkapi kajian penelitian ini, seperti minat, bakat, tingkat kreativitas, dan lain sebagainya.

5. Diadakannya pelatihan bagi guru dalam peningkatan kemampuan dalam merancang strategi pembelajaran

6. Perlu diadakan penelitian yang lebih lanjut dalam penggunaan strategi pembelajaran untuk mengetahui hasil yang lebih akurat.

\section{DAFTAR PUSTAKA}

Anderson, O.W, Krathwohl, D.R. (2001). A Taxonomy for Learning, Teaching, and Assessing. New York: Addison Wesley Longman, Inc

Atkinson, Rita L, dkk. (1999). Pengantar Psikologi. Jakarta: Erlangga

Atmadi, A dan Y. Setyaningsih. (2000). Transformasi Pendidikan Memasuki Millenium Ketiga, Yogyakarta: Kanisius.

Bigge, Morris L. (1982). Learning Theories For Teachers. New York: Harper \& Row

Buchari, Mochtar. (2001). Pendidikan Antisipatoris, Yogyakarta: Kanisius

Campbell, D.T. Stanley, J.C. (1996). Experimental and Quasy Experimental Design For Research. USA: Rand Mc Nally \& Company Chicago

Charles, C.M. (1980). Individualizing Instruction, London: Mosby Company

Cullingford, Cedric. (1995). The Effective Teacher, London: Cassel

Davis, J. (1989). On Matching Teaching Approach with student Learning Style: Are We Asking the Right Question. Memphis, TN: University of Memphis

Dennison, Paul E. dan Dennison, Gail E. (2002). Braim Gym, Jakarta: Gramedia Widiasarana Indonesia.

Dunn, R., \& Dunn, K. (1978). Teaching Students Through Their Individual Learning Styles. Reston V.A: Reston Publishing Co. 
DePorter, B. (2004). Quantum Learning, Terjemahan Alwiyah Abdurrahman, Bandung: Kaifa.

Dimyati. (1994). Belajar dan Pembelajaran, Jakarta: Rineka Cipta.

Fajar, Arnie. (2004). Portofolio dalam pembelajaran IPS, Bandung: PT. Remaja Rosdakarya.

Gagne, Robert M \& Driscoll, Marcy P. (1989). Essentials of Learning for Instruction. New Jersey: Prentice Hall

Gerlach, Vernon S \& Ely, Donald P. (1980). Teaching \& Media, A Systematic Approach. New Jersey: Prentice Hall

Given, Barbara K. (2007). Brain Based Teaching. Bandung: Kaifa

Gunawan, Adi W. (2006). Genius Learning Strategy, Jakarta: Gramedia Pustaka Utama.

Gunawan, Adi W. (2004). Born to be a Genius, Jakarta: Gramedia Pustaka Utama.

Jarolimek, John \& Foster, Clifford D. (1976). Teaching and Learning in the Elementary School. London: Macmillan

Keefe, J.W. (1991). Learning Style: Cognitive and thinking skills. Reston, VA: National Association of Secondary School Principals.

Kemp, Jerrold E. (1977). Instructional Design (A Plan for Unit and Course Develompent). California: David S. Lake Publishers

Kirby, John R. (1984). Cognitif Strategies and Educational Performance. London: Academic Press. Inc

Lu, H., Jia, L., Gong, S.H., \& Clark, B. (2007). The Relationship of Kolb Learning Styles, Online Learning Behaviors and Learning Outcomes Educational Technology \& Society.

MacGregor, Sandy. (2005). Piece of Mind, Jakarta: Gramedia Pustaka Utama.

Madden, Thomas L. (2002). Fire Up Your Learning, Jakarta: Gramedia Pustaka Utama.
Marjoribanks, Kevin. (1991). The Foundation of Students' Learning. Australia: Pergamon Press

Miarso, Yusufhadi. (2007). Menyemai Benih Teknologi Pendidikan. Jakarta: Kencana

Milfayetty, Sri dan Anita Yus. (2005). Pengentasan Masalah Belajar Melalui Strategi Genius Learning, Medan: Yayasan Refleksi Pendidikan.

Muijs, Daniel \& Reynolds, David. (2008). Effective Teaching. Yogyakarta: Pustaka Pelajar

Nasution. (2008). Berbagai Pendekatan dalam Proses Belajar Mengajar. Jakarta: Bumi Aksara

Prashnig, Barbara. (2007). The Power of Learning Styles. Jakarta : Kaifa

Reigeluth, C. M. (1983). Instructional Design Theory of Models: An Overview of Their Current Status. London: Prentice Hall

Romiszwoski, A.J. (1981). Instructional Design System, Decision Making in Course Planning and Curriculum Design. London: Kogan

Rose, Colin dan Malcolm J. Nicholl. (2002). Accelerated Learning For The $21^{\text {St }}$ Century, Bandung: Nuansa.

Sanjaya, Wina. (2008). Strategi Pembelajaran. Jakarta: Kencana

Silberman, Mel. (2000). Active Learning, Yogyakarta: Yappendis.

Syah, Muhibbin. (2008). Psikologi Belajar. Jakarta: RajaGrafindo Persada

Uno, Hamzah B. (2008). Orientasi Baru dalam Psikologi Pembelajaran. Jakarta: Bumi Aksara

Witkin, W. Moore, et al. (1977). Field Dependent and Field Independent Cognitive Style and Their Educational Implication. Review of Educational Research

Zaini, Hisyam dkk. (2002). Desain Pembelajaran di Perguruan Tinggi, Yogyakarta: CTSD IAIN Sunan Kalijaga Yogyakarta 